\title{
ASEAN Financial Integration in the Light of Recent European Experiences*
}

\author{
Ulrich Volz \\ SOAS, University of London and German Development Institute
}

12 MAY 2013

\begin{abstract}
This article reflects on the ambitions of the Association of Southeast Asian Nations (ASEAN) to foster regional economic and financial integration among its member countries against the backdrop of the European financial crisis. Based on a review of the European experiences with financial integration since the 1970s, this article critically examines the potential risks associated with the creation of a financially-integrated ASEAN Economic Community and the implications for policy autonomy of ASEAN members. It outlines the regulatory and institutional requirements that need to be put in place in order to minimize financial stability risk if an integrated financial sector across ASEAN is aimed for.
\end{abstract}

*Paper prepared for a special issue of the Journal of Southeast Asian Economies. The author is grateful for comments received on a presentation given at the ASEC-DIE-CoC Workshop on "Financial and Macroeconomic Cooperation and Integration in ASEAN against the Background of the European Crisis" in Jakarta on 19 March 2013. 


\section{Introduction}

Financial integration is an important part of ASEAN's goal to establish an ASEAN Economic Community (AEC). In 2007, the member states' heads of state/government endorsed the AEC Blueprint that outlines the path to establishing the AEC by 2015. The AEC Blueprint comprises far-reaching plans for financial services liberalization among member states as well as measures aimed at fostering capital market development and integration, including a dismantling of capital account restrictions in order to achieve a "freer flow of capital" across ASEAN. Numerous working committees have been negotiating the modes of liberalization and schedules. The ASEAN central bank governors are currently devising a framework for banking integration that will allow qualified ASEAN banks to operate across the region.

A study published in April 2013 jointly by the Asian Development Bank (ADB) and the ASEAN Secretariat posits that the formation of the AEC "will benefit from the successful liberalization of the capital account and the domestic financial market in individual countries, and from the ASEAN-wide integration of financial markets and institutions supported by regulatory harmonization and the strengthening of policy coordination among the member states" (ADB and ASEAN 2013: 1) ${ }^{1}$. While financial integration can certainly benefit the region and contribute to financial development in the less developed ASEAN economies, there are also substantial risks that come with capital account and financial liberalization. Liberalization will also have far-reaching consequences for national policy autonomy. The financial stability risks as well as implications of close financial integration for policy autonomy have been highlighted by the recent European experiences. Against the backdrop of the European crisis, this article thus reflects on the merits and risks of (regional) financial integration and underscores the great importance of designing an appropriate regulatory and supervisory framework to safeguard financial stability in an integrated area.

The next section will look into the European experiences with financial integration since the 1970s and discuss how regional financial integration contributed to the European crisis and what could have been done differently to prevent it. Section 3 will then turn to the developing framework for ASEAN financial integration and discuss implications and lessons of the European experiences. Section 4 concludes.

\footnotetext{
${ }^{1}$ The study was launched on the sidelines of the Ninth ASEAN Central Bank Governors meeting in Brunei in April 2013. In a press release, the ASEAN Central Bank Governors (2013) stated: "The Summary Report is a joint initiative of the ASEAN central banks and monetary authorities, the ASEAN Secretariat and the Asian Development Bank. The Central Bank Governors view this Report as an important reference for ASEAN to further guide its financial integration process."
} 


\section{European financial integration and the European crisis of 2010-}

\subsection{Background to European financial integration}

From the second half of the 1970s, European policy makers increasingly worked toward an integration of European financial markets, which was widely regarded as being conducive to trade integration and expected to unleash the growth potential of member countries. European financial integration was fostered through market deregulation, which was "shaped both by the abolition of capital account restrictions and the adoption of common legislative standards" (Buch and Heinrich 2003:32). Although some European countries had lifted restrictions on capital flows on an individual basis earlier, the liberalization of capital controls across the European Community was completed only in the early 1990s as the Single European Act of 1986 was implemented to remove all legal barriers to an internal market. Several countries, including Belgium (1991), France (1990), Greece (1994), Luxembourg (1990), Portugal (1992) and Spain (1992), maintained capital controls until then (Table 1). ${ }^{2}$

[Table 1 about here]

The harmonization of regulation and financial integration were propelled by the European Community's First and Second Banking Directives. The First Banking Directive on The Coordination of Laws, Regulations and Administrative Provisions Relating to the Taking Up and Pursuit of Credit Institutions, which was adopted in 1977, was the first step toward the harmonization of banking regulation. In particular, it applied the principle of nondiscrimination against businesses from other member states to the banking sector and established the principle of home country control, according to which responsibility for the supervision of a bank would be gradually transferred from the host to the home country of the parent institution (Dermine 2003). A "single passport" for banks was introduced through the Second Banking Directive of 1989, which was fully implemented by the beginning of 1993 . Under the single passport policy, banking licenses are mutually recognized and a bank

\footnotetext{
${ }^{2}$ The liberalization of capital accounts was actually one factor that contributed to the 1992/93 crisis of the European Monetary System, the fixed exchange rate system that preceded the euro. As Wyplosz (2004:262) pointed out: "In the 10 years between its creation in 1979 and 1990, when capital accounts were freed, there were 12 realignments, most of them involving several currencies. With few exceptions, these realignments came in the wake of speculative attacks, yet the system survived. The first attack that occurred after capital liberalization was lethal".
} 
licensed in any member state can operate freely across the European Economic Area (EEA), ${ }^{3}$ with foreign branches being subject to home country supervision. ${ }^{4}$ Furthermore, the Second Banking Directive harmonized capital adequacy standards.

A further push for financial integration came when the European Council launched the Financial Services Action Plan (FSAP) in May 1999. The FSAP, which comprised numerous initiatives to ensure the full integration of European Union (EU) banking and capital markets by 2005, put forward three strategic objectives: (i) establishing a single EU market in wholesale financial services; (ii) making retail markets open and secure; and (iii) development of state-of-the-art prudential rules and supervision (EU 2006). The FSAP was endorsed by the Lisbon European Council in March 2000 and implementation started in 2001.

Research by Kalemli-Ozcan et al. (2010:77) has shown that legislative-regulatory harmonization policies in financial services have contributed decisively to the deepening of European financial markets and that "cross-border banking activities increased significantly among European countries that quickly adopted the financial services Directives of the FSAP". This indicates that "financial services legislative harmonization is a significant driver of banking integration" (ibid.).

Moreover, financial integration was fostered through European Monetary Union and the adoption of the euro as a single currency by 11 member states in $1999 .^{5}$ As highlighted by the ECB (2012a:108), "the catalytic effect of European Monetary Union [...] fostered a continuing process of integration in European financial markets and brought about a surge in intra-euro area cross-border investment". ${ }^{6}$ According to estimates by Kalemli-Ozcan et al. (2010), crossborder bilateral bank holdings and transactions rose by about 40 per cent among eurozone members after the introduction of the euro. A major factor behind the increase in financial integration among eurozone members was the elimination of currency risk. ${ }^{7}$ However, it should be noted that integration in the different segments of the financial markets advanced at a different pace: while integration in the bond, equity, and wholesale banking markets

\footnotetext{
${ }^{3}$ The EEA comprises the member countries of the EU plus Iceland, Liechtenstein, and Norway.

${ }^{4}$ According to Dermine (2003), "[t]he Second Banking Directive called for home country control on solvency, which, under this directive, extends to the bank itself, its foreign and national subsidiaries which have to be consolidated for supervisory purposes, and its foreign branches. With regard to the latter, the host state retains the right to regulate a foreign bank's activities in that state only to the extent that such regulation is necessary for the protection of 'public interest'."

${ }^{5}$ Belgium, Germany, Greece, Spain, France, Ireland, Italy, Luxembourg, the Netherlands, Austria, Portugal and Finland. Six countries joined later: Greece (2001), Slovenia (2007), Cyprus (2008), Malta (2008), Slovakia (2009) and Estonia (2011).

${ }^{6}$ See also ECB (2006).

${ }^{7}$ See also Kalemli-Ozcan et al. (2010).
} 
progressed rapidly, integration of the retail banking market was slow (Kleimeier and Sander 2007).

\subsection{How did financial integration contribute to the European crisis? ${ }^{8}$}

Financial and monetary integration led to a big drop in nominal and real interest rates in the periphery countries. The expanded access to funding from abroad and the drop in real interest rates in the periphery countries set off a boom which attracted further capital inflows. These were reinforced because several Northern European countries, most notably Germany, had entered the euro with an overvalued exchange rate which dampened economic activity there. Since investment opportunities looked much better in the periphery countries at the time, capital flew from the core countries to the periphery, fuelling their booms. That the risk of central government bonds of eurozone member countries was weighted at zero in regulatory capital calculations and the fact that the Eurosystem (the ECB and the national central banks) treated such debt with no haircut when these were offered as collateral for repos and other collateral financing trades fuelled appetite for investment in sovereign bonds of periphery countries which still yielded slightly higher returns than those of center countries.

The large flows of capital from the centre to the periphery fuelled excessive credit dynamics, construction sector booms and real estate bubbles (Ireland, Spain), and excessive fiscal spending (Greece). The booms also led to rising unit labor costs and real exchange rate appreciation, causing a loss of economic competitiveness of the periphery countries vis-à-vis the center countries and current account deficits to widen.

In essence, the European crisis followed a pattern similar to that seen in numerous developing and emerging market crises before, even if the channels of contagion effects differed because of the common currency. Today's European crisis countries experienced what a large number of developing and emerging countries (including those in Southeast Asia) went through over the past decades: a period of strong yet unsustainable output growth fuelled by capital inflow surges - or "capital flow bonanzas" as Reinhart and Reinhart (2009) call them - was followed by a "sudden stop" (Calvo 1998). At that point, financial integration through private markets stalled and went into reverse (Watson 2012). The reversal of private capital flows raised risk premiums which worsened governments' fiscal positions and forced painful adjustments in the crisis economies.

\footnotetext{
${ }^{8}$ The focus here is how financial integration contributed to the crisis, not on overall explanation of crisis causes. For a more comprehensive analysis of the causes behind the European crisis see, for instance, Volz (2012a).
} 
The capital flow bonanzas in the periphery countries were made possible because of unrestricted capital flows and tightly integrated banking and capital markets. ${ }^{9}$ Macroprudential regulation that could have prevented excessive credit dynamics and the development of financial and property bubbles was not in place since prudential policies concentrated on the micro level only.

Although much blame for the crisis was put on thriftless government spending (including supposedly too generous spending on social security and public welfare) in public discourse, as a matter of fact public finances in most of today's crisis countries (with Greece and Italy as major exceptions) were broadly okay before the outbreak of the Global Financial Crisis (GFC) and deteriorated after its outbreak. As shown in Table 2, public debt to GDP stood at 68.4 per cent in Portugal in 2007, while Ireland and Spain had public debt to GDP ratios of 25.1 per cent and 36.3 per cent, respectively, much lower than the 60 per cent ratio stipulated by the EU's Stability and Growth Pact. In the crisis countries but also elsewhere in Europe, public finances deteriorated rapidly when governments responded with anti-cyclical policies to the GFC and prolonged recessions. Fiscal positions worsened as tax revenues declined and transfer payments grew larger due to rising unemployment during the crisis. In several countries, government bailouts of ailing banking systems also contributed to an increase in public debt. ${ }^{10}$

[Table 2 about here]

The worsening of public finances and increases in sovereign risk in the eurozone had profound effects on European banks, which had already taken a hit during the GFC due to their exposure to the US financial sector. Since most eurozone governments failed to recapitalize banks swiftly after the 2008-2009 crisis, their weak banks had severe problems coping with deteriorating sovereign risk, which in turn fueled the fear that further bank

\footnotetext{
${ }^{9}$ Or, as Subramanian put it, "[f]ree capital mobility allowed surpluses from large savers such as Germany to flow to capital importers such as Spain, while the perceived elimination of currency risk served to aggravate such flows. To investors, Spanish housing assets seemed a great investment, because the forces of economic convergence unleashed by the euro would surely push up their prices - and because there was no peseta that could lose value. These capital flows created a boom - and a loss of long-term competitiveness - in some regions, which was followed by an all-too-predictable bust."

${ }^{10}$ The most dramatic increase in public debt - from 25.1 per cent in 2007 to 106.4 per cent in 2011 - happened in Ireland, where the GFC and the bursting of the property bubble brought the country's banks to the brink of collapse. Under pressure from other countries (whose banks were creditors to Irish banks) and the European Central Bank, the Irish government guaranteed most liabilities of Irish-owned banks.
} 
bailouts would be needed and thereby increased sovereign risk of their home country even more. As pointed out by Véron (2011), the interdependence between sovereign credit and banking systems has been at the heart of the crisis since sovereign debt of eurozone countries are held in large quantities by eurozone banks. Moreover, European banks held large amounts of sovereign debt not only from their home country but also from other eurozone countries. The large cross-border exposures to sovereign debt of other eurozone countries caused a systemic crisis of the entire European banking system which proved hard to handle because the eurozone lacked the institutional mechanisms to deal with such problems, including a common resolution authority to deal with failing banks. As Véron (2011:1) put it, a vicious circle was set in motion in which "twin sovereign and banking crises [...] mutually feed each other" and lead to a "gradual contagion to more countries and more asset classes". In this sense, the European banking and sovereign debt crisis is a consequence and continuation of the GFC.

\subsection{What could have been done differently to prevent the crisis?}

Of course, the crisis was not inevitable. Macroprudential regulation could have been employed at the national level to curtail excessive lending by domestic banks and tame capital inflows. This would have helped to avoid property bubbles and the build-up of vulnerabilities in the financial sector. In several countries, especially in Ireland and Cyprus where financial authorities had deliberately adopted a light-touch regulatory approach to attract foreign investments, a stricter regulation of financial markets could have prevented the development of an oversized banking sector which later proved too-big-to-rescue for these countries. Spanish banking supervisory authorities, which were praised at the onset of the GFC for having prevented Spanish banks from investing in subprime assets in the US, should have restrained the country's savings banks in financing an unsustainable construction boom which later left them with an enormous non-performing loans problem.

Moreover, policymakers could and should have taken early action to prevent the widening of intra-European macroeconomic imbalances. At the national level, economic policies should have encouraged wage growth in line with productivity growth to avoid real exchange rate appreciation and the loss of long-term competitiveness within the monetary union. The benign economic environment that periphery countries enjoyed after adopting the euro should have been used by governments to carry out structural reform policies to bring their economies in line with the requirements of eurozone membership. 
At a broader lever, there was a failure to engage in macroeconomic and fiscal coordination among eurozone governments, which pursued economic policy as if they were still independent economies and not part of a monetary union. ${ }^{11}$ The lack of macroeconomic and fiscal coordination at the European level resulted in divergent wage and price developments and macroeconomic imbalances within the eurozone, as discussed above.

Moreover, the crisis "revealed weaknesses not only in the risk management of many financial institutions, but also in the design of supervisory structures and the execution of financial supervision" (Speyer 2011:3). In particular, the EU and its member countries failed to create a union-wide regulatory structure to effectively supervise pan-European banks. ${ }^{12}$ Although regulation was harmonized across the EU through the First and Second Banking Directives and European banks were engaged in extensive cross-border activities across the EU, financial market supervision rested entirely with the member countries. Not only did the EU fail to create a European financial supervisory authority, it turned out there was also a lack of exchange and cooperation between national supervisory authorities. The European Commission (2009) summarized the problem as follows:

\begin{abstract}
"Experience of the financial crisis has exposed important failures in financial supervision, both in particular cases and in relation to the financial system as a whole. Current supervisory arrangements proved incapable of preventing, managing and resolving the crisis. Nationally-based supervisory models have lagged behind the integrated and interconnected reality of today's European financial markets, in which many financial firms operate across borders. The crisis exposed serious failings in the cooperation, coordination, consistency and trust between national supervisors". ${ }^{13}$
\end{abstract}

Clearly, it was a mistake to push for financial integration without developing an appropriate pan-European institutional framework for supervision and resolution of financial institutions. The crisis has underscored "the importance of an integrated approach to the EU financial

\footnotetext{
${ }^{11}$ The Stability and Growth Pact - which requires EU member countries to have an annual budget deficit no higher than 3 per cent of GDP and a national debt lower than 60 per cent of GDP or approaching that value was suspended in 2003 under pressure from France, Germany, and Italy which had violated it (along with Portugal and Greece). It was revised and effectively watered down in 2005.

${ }^{12}$ Steps towards the creation of European supervisory authorities to help oversee Europe's financial sector from a pan-European perspective were taken only in late 2008, when the president of the European Commission mandated a high-level expert group on financial supervision in the EU. The expert group, led by Jacques de Larosière, proposed three new supervisory authorities, which were established in November 2010 and started operation in January 2011: the European Banking Authority (EBA) based in London; the European Securities and Markets Authority (ESMA) based in Paris; and the European Insurance and Occupational Pensions Authority (EIOPA) based in Frankfurt. These three supervisory authorities were complemented by the creation of the European Systemic Risk Board (ESRB), which is responsible for the macroprudential oversight of the financial system within the EU and which has a secretariat hosted by the ECB. Together, these institutions form the new European System of Financial Supervision.

${ }^{13}$ The ECB (2012b:31) also conceded that "[t]he financial crisis laid bare a number of weaknesses in the institutional setup supporting the single financial market and brought the process of financial integration to a halt."
} 
safety net", comprising "prudential supervision, deposit insurance, reorganization and winding up, and lending of last resort" (Garcia et al. 2009:2). ${ }^{14}$ Details of a prospective "banking union" are now being discussed, which may include three elements: a single banking supervisor; a single resolution authority to deal with failing banks; and a single safety net to protect depositors. ${ }^{15}$

Regarding liquidity support for member governments, it is almost ironic that the EU's Medium-term Financial Assistance facility, which was originally designed in 1970 to deal with balance-of-payments problems of all member states of the European Community/EU, has been restricted since 1999 to EU member countries which have not adopted the euro (McKay et al. 2010). In the midst of crisis, European policymakers hence faced the challenge of crafting a response from scratch, first agreeing on bilateral lending to Greece and when this appeared insufficient, on the creation of the European Financial Stability Facility (EFSF) and the European Financial Stability Mechanism (EFSM).

\section{Framing ASEAN financial integration}

\subsection{ASEAN's evolving roadmap for financial integration}

The move toward fostering financial integration in ASEAN dates back to 1997, when the ASEAN heads of state/government declared in the ASEAN Vision 2020 the goal of creating "a stable, prosperous and highly competitive ASEAN Economic Region in which there is a free flow of goods, services and investments, a freer flow of capital, equitable economic development and reduced poverty and socio-economic disparities" (ASEAN 1997). To this end, the ASEAN leaders pledged to "promote financial sector liberalisation and closer cooperation in money and capital market, tax, insurance and customs matters as well as closer consultations in macroeconomic and financial policies" (ibid.).

Several initiatives followed. In October 1998, the ASEAN finance ministers launched the ASEAN Surveillance Process (ASP) "as a mechanism for peer review and exchange of views among the senior officials (central bank and finance) and Finance Ministers on recent economic developments and policy issues in ASEAN" (ASEAN 2013).

\footnotetext{
${ }^{14}$ The European Community Directive on the Reorganization and Winding-Up of Credit Institutions (Directive 2001/24/EC of the European Parliament and of the Council of 4 April 2001) was actually hoped to "provide a greater deal of efficiency and certainty in bank insolvency proceedings" (Campbell 2005), especially in the context of an international bank insolvency. With hindsight, one can conclude that this did not work.

${ }^{15}$ See, for instance, the contributions in Beck (2012).
} 
In 2003, the ASEAN finance ministers agreed on a Roadmap for Monetary and Financial Integration of ASEAN, which laid down the way towards integration of financial markets, including "steps, timelines and indicators of activities in four areas: (a) Capital Market Development, (b) Liberalisation of Financial Services, (c) Capital Account Liberalisation and (d) ASEAN Currency Cooperation" (ASEAN 2013). ${ }^{16}$

In November 2007, the ASEAN head of states/government adopted the AEC Blueprint, which envisages the implementation of an AEC by $2015 .{ }^{17}$ In order to achieve the goal of single market and production base, the AEC Blueprint comprises far-reaching plans for financial services liberalization among member states as well as measures aimed at fostering capital market development and integration (see Box 1). In particular, it envisages a "free flow of services" across ASEAN that shall apply also to the financial services sector. It puts forward "[1]iberalisation measures of the financial services sector [that] should allow members to ensure orderly financial sector development and maintenance of financial and socio-economic stability" (\$22). It explicitly states that financial liberalization measures should proceed according to the specific situation of the individual member country ("with due respect for national policy objectives and the level of economic and financial sector development of the individual members", §22(b)).

[Box 1 about here]

In Section A4 on a "freer flow of capital", the AEC Blueprint calls for several actions for strengthening ASEAN capital market development and integration, including a harmonization of capital market standards; facilitation of linkages between national exchange and debt markets; changes to the taxation of cross-border capital earnings; and the mutual recognition of qualification of financial sector professionals.

Last but not least, the Blueprint also envisages greater capital mobility and demands from member countries to "[r]emove or relax restrictions on capital flows, where appropriate and possible, to support foreign direct investment and initiatives to promote capital market development" (\$32ii.).

\footnotetext{
${ }^{16}$ Already, the ASEAN Framework Agreement on Services (AFAS) of 1995 envisaged a gradual and sequenced liberalization of identified financial services sub-sectors.

${ }^{17}$ The goal of establishing the AEC was declared in the Bali Concord II in October 2003 (cf. ASEAN 2003). Initially, the AEC was to be established by 2020 but at the 12th ASEAN Summit in Cebu in January 2007, ASEAN leaders decided to accelerate the establishment of the AEC to 2015.
} 
The Strategic Schedule for ASEAN Economic Community (ASEAN Secretariat 2008:30-55) pinned down tentative timeframes for achieving the various measures listed in the Blueprint, but remained vague regarding financial services sector liberalization, capital market development, and integration and capital account liberalization. Over the recent years, several further initiatives or schemes have been launched, including the ASEAN Capital Markets Forum Implementation Plan to Promote the Development of an Integrated Capital Market to Achieve the Objectives of the AEC Blueprint 2015 ${ }^{18}$; the Working Committee on Capital Account Liberalization Work Plan; and the ASEAN Financial Integration Framework (AFIF), which was endorsed by the ASEAN central bank governors in April 2011. In April 2013, the central bank governors endorsed in principle the ASEAN Banking Integration Framework (ABIF), under which "qualifying ASEAN banks that have the capacity and that are well managed [...] will be accorded more flexible access into regional markets" (Aziz 2012:2-3).

\subsection{What lessons for ASEAN financial integration can be drawn from the European experience?}

Notwithstanding the current financial crisis in Europe, it should be emphasized that the empirical evidence suggests that the European financial integration process did generate tangible economic benefits in terms of increased firm investment (Bris et al. 2006), improved cost efficiency in European banking (Weill 2009), and a decline in nominal and real financing costs for European households and firms (ECB 2012b). ${ }^{19}$

The lesson for ASEAN should therefore not be that financial integration brings only risks and no benefits. Especially for the less developed ASEAN economies, financial integration can be an important contributor to financial development - including both banking and capital markets - and improve access to finance for firms and households. However, ASEAN countries need to make sure to mitigate the risks that come with financial liberalization and capital account opening as they try to create integrated ASEAN financial markets. Building on the above review of the European experiences with financial integration, the remainder of

\footnotetext{
${ }^{18}$ The ASEAN Capital Markets Forum was established in 2004 and comprises the capital market regulators of all ASEAN members. For the ASEAN Capital Markets Forum Implementation Plan to Promote the Development of an Integrated Capital Market to Achieve the Objectives of the AEC Blueprint 2015, see ASEAN Capital Markets Forum (2009).

${ }^{19}$ As the ECB (2012b:43) puts it: "Households and corporations from all euro area countries have benefited to substantial, but varying, degree from significantly lower financing costs." It should be borne in mind, however, that it was the very success of monetary and financial integration in bringing down financing costs, especially in periphery countries, that enabled these countries' credit booms and sowed the seed of crisis.
} 
this section will discuss several questions that ASEAN policymakers should contemplate when deciding on ASEAN's proposed financial integration process.

\section{How far should capital account liberalization go?}

Several ASEAN countries, along with Korea, learned during the Asian Financial Crisis the hard way that capital account liberalization carries substantial risks. As a result, there is a high awareness in the region of the perils of capital account opening, which is also the reason why several ASEAN countries still maintain rather strict capital controls (Figure 1, Table 3).

[Figure 1 and Table 3 about here]

More financial integration is not necessarily better, especially for smaller economies with less developed financial systems and a relatively low level of institutional development such as the BCLMV countries (Brunei Darussalam, Cambodia, Laos, Myanmar and Vietnam). International financial integration can have serious implications for macroeconomic and financial stability; it increases contagion risk as well as the risk of capital flow bonanzas, sudden stops, and a reversal of flows. These risks are especially large for developing countries with shallow financial sectors where even small capital movements can have strong effects on domestic markets and the exchange rate. It should also be pointed out that capital account liberalization would have profound impact on countries' abilities to manage their exchange rate, something all ASEAN countries have been doing to different extent.

Research has shown that the benefits of financial integration can only be reaped when countries attain a certain level of institutional and regulatory development (or "threshold conditions"). ${ }^{20}$ Hence, it is very sensible that the AEC Blueprint put forward three broad principles that shall guide the liberalization of capital movements: "a) Ensuring an orderly capital account liberalisation consistent with member countries' national agenda and readiness of the economy; b) Allowing adequate safeguard against potential macroeconomic instability and systemic risk that may arise from the liberalisation process, including the right to adopt necessary measures to ensure macroeconomic stability; and c) Ensuring the benefits of liberalisation to be shared by all ASEAN countries."

\footnotetext{
${ }^{20}$ See Chinn and Ito (2006), Kose et al. (2009), Frey and Volz (2013) and Garcia and Volz (2013).
} 
These principles have been reaffirmed in the recent ADB-ASEAN study (ADB and ASEAN 2013). The same study, however, insists that "[f]ull and complete capital account and financial services liberalization is ultimately key to the success of the AEC. Though a gradual and judicious approach is the only pragmatic and feasible option at the present, this must be considered as a step toward the eventual elimination of all restrictions on crossborder capital flows and financial services" (ADB 2013:27). This raises two questions. First, how fast can capital account liberalization in the BCLMV countries but also in Indonesia, Malaysia, the Philippines, and Thailand proceed without doing more harm than good? From experiences with capital account liberalization of the past decades, including the European experiences, there is good reason to be cautious and liberalize at a rather slow pace. Second, one ought to ask the question whether "[f]ull and complete capital account and financial services liberalization" (ibid.) really ought to be the goal for all ASEAN members in the foreseeable future? After all, "[t]here is still little robust evidence of the growth benefits of broad capital account liberalization" (Kose et al. 2011:8). ${ }^{21}$

In any case, as capital accounts are liberalized, it will be of utmost importance for monetary and financial authorities to closely monitor capital flows and have policy tools at their disposal to respond to capital inflow surges or disruptive outflows. Recent experience has shown that macroprudential regulation is of particular importance to deal with strong capital inflows. Moreover, even in an economy that has already reached an advanced stage of capital account liberalization, policymakers should stand ready to re-impose (temporary) capital controls if other policies, including monetary, fiscal, and macroprudential policies do not suffice to mitigate risks.

As ASEAN countries liberalize capital accounts, it will also be crucial to further develop a comprehensive regional financial safety net. The Chiang Mai Initiative Multilateralization (CMIM) has made important progress over the past years, especially with the establishment of the ASEAN+3 Macroeconomic Research Office in Singapore in April 2011 and the decision in May 2012 to double the amount available under the CMIM to USD 240 billion. Yet, there is still much to do to make the CMIM effective; in particular, ASEAN+3 countries need to find agreement on the so-called IMF-linkage, which currently stipulates that a country can only access 30 per cent of the funds available from the CMI without having a IMF program (cf. Volz 2012b). Given the political stigma the IMF still has in the region, the IMF-link

\footnotetext{
${ }^{21}$ ADB and ASEAN (2013:13) maintain that "[t]here is a compelling economic case for free capital mobility in ASEAN" because "it aids in the efficient allocation of the region's large savings across national borders, and therefore promotes economic growth and welfare."
} 
(which the two biggest contributors to the CMIM, China and Japan, insist on) essentially prevents countries from seeking assistance from the CMIM. ${ }^{22}$

What kind of regional financial architecture is needed to ensure stability within a financially integrated $A E C$ ?

Several reports have highlighted that financial integration requires regional institution building to ensure effective regional monitoring and surveillance. For instance, ADB and ASEAN (2013:27) assert that "[t]o make [full and complete capital account and financial services liberalization] safe and possible, the ASEAN member states must start creating and strengthening the requisite regional institutions."

While there is a lot of talk of strengthening regional surveillance, there is little discussion about the concrete form of institution building that is required. The European experience shows clearly that from a certain level of regional financial integration, there is a need for a strong regional supervisory structure. While ASEAN is still quite far from the level of financial integration that the EU has attained, there needs to be clarity of the implications of a unified financial market if this is what is to be achieved in ASEAN.

The banking crisis in Europe has shown that a system of financial supervision based on the principle of home country control combined with minimum standards and mutual recognition does not work in a closely integrated financial market and that the latter requires not only close collaboration of national supervisors, but common supervisory authorities. Indeed, there appears to be a "financial trilemma" (Schoenmaker and Oosterloo 2008, Schoenmaker 2011) akin to the trilemma in international macroeconomics. According to the financial trilemma, "financial stability, financial integration and national financial policies are incompatible" (Schoenmaker 2011:57), and only two of these objectives can be achieved at a time (Figure 2). As pointed out by Cœuré (2013), "[n]ational financial policies fail to recognise the externality generated by cross-border banks in difficulty. As a result, they generate underprovision of supervision, then of capital for troubled banks with a cross-border and/or systemic component. In addition, national supervisors may more easily be subject to regulatory capture. Both facts undermine financial stability."

[Figure 2 about here]

\footnotetext{
${ }^{22}$ Indonesia and Korea actually needed support during the GFC but did not seek CMIM support.
} 
Even if the financial trilemma gives a stylized view of reality, ASEAN countries will have to engage in a discussion on how they want to navigate the financial trilemma and what degree of sovereignty they would be willing to transfer to a regional supervisory body. As pointed out, by ADB and ASEAN (2013:8), "instituting a uniform regulatory structure across a region with many sovereign states at different stages of development is a daunting task as it infringes on national sovereignty". However, if ASEAN countries want to launch an ABIF, adequate provisions will be needed to ensure an ASEAN-wide supervision of "qualified banks" that obtain a single "passport" to operate in any ASEAN country. Moreover, ASEAN supervisory authorities should put in place an adequate legal and institutional framework for bank resolution procedures that will also work for banks operating across borders. As can be seen in Europe, where questions about a pan-European supervision of banks were long shelved, they eventually need to be answered and it is better to deal with this issue before crises erupt. If ASEAN members are hesitant to transfer banking supervision powers to a regional body, then they should not aim for a single market in banking.

\section{What kind of banking system shall ASEAN develop?}

ASEAN countries also ought to consider what kind of banking systems they want to create. There is a good case for liberalizing cross-border banking services to improve efficiency and reduce cost in banking throughout ASEAN. There is also the danger that too much deregulation will contribute to the development of an overly complex banking system and the emergence of banking institutions that are too-big-to-fail - and too-big-to-rescue.

After pointing out that "the market capitalization of all of the 24 ASEAN commercial banks combined is smaller than that of Industrial and Commercial Bank of China (ICBC), China Construction Bank, or Hongkong and Shanghai Banking Corporation (HSBC)", ADB and ASEAN (2013:4) argue that "ASEAN needs to nurture globally competitive banks". Furthermore, they anticipate that "[t]he integration of ASEAN banking institutions will create an environment conducive to the emergence of such banks. It will build up a customer base large enough to support the growth of large competitive banks with a foothold in global banking through mergers and the acquisition of small banks" (ibid.). While ASEAN should certainly strive to develop competitive banking systems, a vision that emphasizes the development of "large competitive banks with a foothold in global banking" may be a very risky one as it fails to take account of one of the major lessons of the GFC, namely that large, 
internationally active banks are complex and difficult to supervise, and that financial firms that are too-big-to-fail can "become major risks to overall financial stability" (Bernanke 2010:21). US Fed Chairman Bernanke (2010:21) even went so far as to say that "[i]f the crisis has a single lesson, it is that the too-big-to-fail problem must be solved."

Malaysian central bank governor Azis (2012:3) recently emphasized that currently "[t]here is a fundamental rethinking of banking by the international community in the aftermath of the recent global crisis" and that one of the lessons is a need "for reduced complexity and increased transparency in the banking sector." He further points out that

"[c]onsistent with the more traditional banking models in this region, there are now increasing calls for a return to basic banking and its clear separation from higher risk-taking activities. [...] While the banking sector in ASEAN has not reached the degree of complexity observed in the advanced economies, the region has to be mindful of the consequences as financial institutions evolve to become increasingly regional in orientation. Indeed, such growth must be commensurate with the capacity and capability of both the financial institutions and the regulators to manage and oversee the associated risks. [...] ASEAN will have to pursue an outcome that facilitates innovation and efficiency, without resulting in undue risks and unwanted costs on both the financial system and the overall economy." (ibid.) $)^{23}$

When creating an integrated market for banking across ASEAN, the focus should be on developing banking services that matter for the real economy - and not whether ASEAN banks will be able to become internationally leading banks. ${ }^{24}$ With respect to fostering regional economic integration, transaction banking, especially trade finance, will be particularly important for ASEAN. ${ }^{25}$ In wholesale banking, an area where ASEAN banks can make important contributions is infrastructure finance. The developing and emerging economies of ASEAN have enormous financing needs to upgrade their infrastructure, with

\footnotetext{
${ }^{23}$ Similarly, former Bank of Japan governor Shirakawa (2012:2) pointed out that "Asian banks have been known for their traditional or basic business models, in which loans are funded primarily by domestic deposits. In fact, the loan-to-deposit ratios are below 100 percent in many Asian countries. Business models built on such domestic deposits are less susceptible to an acute funding squeeze than models dependent on wholesale funding. I think this feature has also provided Asian banks with some advantages over their Western counterparts in weathering the current crisis."

${ }^{24}$ In this respect, it is interesting to note that in the 1990s and 2000s European governments were similarly concerned with having strong "national champions" that could compete with Wall Street or City banks. For instance, as late as September 2008, the German government welcomed the takeover of Dresdner Bank by Commerzbank (which had to be bailed out a few months later, in January 2009): "Whether in market capitalization or total assets: in international comparison, German banks are not on the front ranks in Europe or even in the world. [...] The merger is an opportunity to consolidate the German financial center, which is in the interest of the business location Germany" (Bundesregierung 2008:4).

${ }^{25}$ As the consulting firm Oliver Wyman (2012:12) points out: "Transaction banking provides a strong platform for a bank's regional ambitions because it helps local corporates to achieve their regional growth objectives. Domestic banks have entrenched relationships with their corporate client base, typically grounded in credit and an onshore cash management and trade offering. This gives them a natural starting point to build a cross-border relationship. Given the rapid rise in intra-regional trade, trade finance is expected to be a particularly important part of the transaction banking opportunity for internationalizing Asian banks."
} 
investment needs estimated at around USD 70 billion per year (e.g. Chaudhuri et al. 2011). ${ }^{26}$ Transaction banking and infrastructure financing are areas where ASEAN banks can make important contributions to regional development. Yet ASEAN regulators should be careful to avoid the emergence of excessively complex banking systems. It will be better to have "boring banks" with a strong regional foothold that contribute to the development of the real economy rather than globally active super-banks whose activities can be a serious threat to financial stability.

\section{Conclusion}

With the AEC, ASEAN has embarked on an ambitious integration program that also envisages integrated financial markets across ASEAN. The article has focused on the risks associated with financial integration which have been accentuated by the recent European experiences. It tried to illustrate that financial integration without an appropriate supervisory framework has been a major factor behind the European crisis. It should be pointed out, however, that financial integration can also bring about substantial benefits if flanked by an appropriate regulatory, supervisory, and macroprudential framework. ASEAN countries will have to make sure to develop such a framework if they want to pursue their goal of achieving a financially integrated single market.

With respect to European financial integration, Speyer (2011:1) highlights how important it has become for European countries to adopt a union-wide supervisory framework:

"The financial crisis has demonstrated that the co-existence of national supervision and integrated financial markets is untenable. Hence, the choice is between either preserving an integrated financial market in the EU and creating a corresponding EU-level supervisory framework for it, or allowing the refragmentation of Europe's financial markets. The choice is clear."

ASEAN countries are still at an early stage of financial integration. It should be clear, however, that a closely integrated financial market would require ASEAN member countries to transfer substantial powers from national supervisors to an ASEAN-level supervisory framework in order to guard financial stability. This would be a very far-reaching political decision for ASEAN member countries.

Whatever the degree of financial integration will be aimed at in the end, experience with capital account liberalization has shown that sequencing matters greatly and that the

\footnotetext{
${ }^{26}$ Various initiatives have been launched to support investment in infrastructure, including the $A S E A N$ Infrastructure Fund and the Master Plan for ASEAN Connectivity.
} 
dismantling of capital controls should be accompanied by the development of macroprudential policies. Especially for the BCLMV countries, whose financial sectors are still shallow, capital account liberalization should proceed very gradually. In this respect, the envisaged double-track implementation of banking and capital markets integration is sensible, where the less developed countries pursue financial services liberalization and especially capital account liberalization at a more measured pace that the more advanced ASEAN members.

\section{References}

ADB and ASEAN. (2013). "The Road to ASEAN Financial Integration: A Combined Study on Assessing the Financial Landscape and Formulating Milestones for Monetary and Financial Integration in ASEAN". Manila: Asian Development Bank.

ASEAN. (1997). "ASEAN Vision 2020". Kuala Lumpur, 15 December. Available: http://www.asean.org/news/item/asean-vision-2020

ASEAN. (2003). "Declaration of ASEAN Concord II (Bali Concord II)". Bali, 7 October. Available: http://www.asean.org/news/item/declaration-of-asean-concord-ii-bali-concord-ii ASEAN. (2013). "ASEAN Finance Ministers Meeting (AFMM). Regional Cooperation in Finance". Available: http://www.asean.org/communities/asean-economiccommunity/category/asean-finance-ministers-meeting-afmm ASEAN Capital Markets Forum. (2009). "The Implementation Plan". Endorsed at the 13th ASEAN Finance Ministers Meeting, Pattaya, 9 April. Available: http://www.theacmf.org/ACMF/report/ImplementationPlan.pdf ASEAN Central Bank Governors. (2013). "The Road to ASEAN Financial Integration", Press Statement, 3 April. Available:

http://www.bnm.gov.my/index.php?ch=en_press\&pg=en_press_all\&ac=2791\&lang=en ASEAN Secretariat. (2008). ASEAN Economic Community Blueprint. Jakarta: ASEAN Secretariat.

Aziz, Z.A. (2012). "ASEAN - Towards a More Integrated Market". Keynote speech at the 19th ASEAN Banking Conference 2012 “ASEAN - Towards a More Integrated Market”, Kuala Lumpur, 7 November. 
Beck, T. (Ed.). (2012). Banking Union for Europe. Risks and Challenges. London: Centre for Economic Policy Research.

Bernanke, B.S. (2010). "Causes of the Recent Financial and Economic Crisis", Testimony Before the Financial Crisis Inquiry Commission, Washington, D.C., 2 September. Available: http://www.federalreserve.gov/newsevents/testimony/bernanke20100902a.htm

Bris, A., Y. Koskinen and M. Nilsson. (2006). "The Real Effects of the Euro: Evidence from Corporate Investments". Review of Finance. Vol. 10(1), pp. 1-37.

Buch, C.M. and R.P. Heinrich. (2003). "Financial Integration in Europe and Banking Sector Performance", in: P. Cecchini, F. Heinemann and M. Jopp (Eds.). The Incomplete European Market for Financial Services. Heidelberg: Physica Verlag, pp. 31-64.

Bundesregierung. (2008). "Schwerpunkt Finanzplatz Deutschland". Magazin Wirtschaft und Finanzen. No. 062 09, 4. Available:

http://www.bundesregierung.de/Content/DE/Magazine/MagazinWirtschaftFinanzen/062/Anla gen/magazin-fuer-wirtschaft-und-finanzen-62-pdf.html

Calvo, G.A. (1998). "Capital Flows and Capital-Market Crises: The Simple Economics of Sudden Stops". Journal of Applied Economics. Vol. 0 (November), pp. 35-54.

Campbell, A. (2005). "Issues in Cross-Border Bank Insolvency: The European Community Directive on the Reorganisation and Winding-Up of Credit Institutions", in: IMF (Ed.), Current Developments in Monetary and Financial Law. Washington, D.C.: International Monetary Fund.

Chaudhuri, R., H.V. Vinayak and J.M. Poullet. (2011). "Capturing the Investment-banking Opportunity in ASEAN". McKinsey Quarterly, March.

Chinn, M.D. and H. Ito. (2006). "What Matters for Financial Development? Capital Controls, Institutions, and Interactions". Journal of Development Economics. Vol. 81(1), pp. 163-92.

Chinn, M.D. and H. Ito. (2008). "A New Measure of Financial Openness". Journal of Comparative Policy Analysis. Vol. 10(3), pp. 309-322.

Cœuré, B. (2013). "The Way Back to Financial Integration", Speech at the Conference "International Financial Integration and Fragmentation: Drivers and Policy Responses" organised by the Banco de España and the Reinventing Bretton Woods Committee, Madrid, 12 March. Available: http://www.ecb.europa.eu/press/key/date/2013/html/sp130312.en.html 
Dermine, J. (2003). "European Banking, Past, Present, and Future", in: V. Gaspar, P.

Hartmann and O. Sleijpen (Eds.). The Transformation of the European Financial System

(Second ECB Central Banking Conference). Frankfurt am Main: European Central Bank, pp. $31-96$.

ECB. (2006). "The Contribution of the ECB and the Eurosystem to European Financial Integration". Monthly Bulletin. May, pp. 61-73.

ECB. (2012a). "Euro Area Cross-border Financial Flows". Monthly Bulletin. February, pp. 105-118.

ECB. (2012b). Financial Integration in Europe. Frankfurt am Main: European Central Bank. EU. (2006). "Financial Services Action Plan (FSAP)". Summaries of EU Legislation, July 4. Available:

http://europa.eu/legislation_summaries/internal_market/single_market_services/financial_serv ices_general_framework/124210_en.htm

European Commission. (2009). "European Financial Supervision". Communication from the Commission COM (2009) 252 final, Brussels, 27 May.

Frey, L. and U. Volz. (2013). "Regional Financial Integration in Sub-Saharan Africa - An Empirical Examination of its Effects on Financial Market Development". South African Journal of Economics. Vol. 81(1), pp. 79-117.

Garcia, G.G.H., R.M. Lastra and M.J. Nieto. (2009). "Bankruptcy and Reorganization Procedures for Cross-border Banks in the EU: Towards an Integrated Approach to the Reform of the EU Safety Net". Special Paper 186, LSE Financial Markets Group Paper Series. May, London: London School of Economics.

Garcia, M.M. and U. Volz. (2013). "Does International Financial Integration Improve Access to Finance?", mimeo, London: SOAS, University of London.

Kalemli-Ozcan, S., E. Papaioannou and J.-L. Peydró. (2010). "What Lies Beneath the Euro's Effect on Financial Integration? Currency Risk, Legal Harmonization, or Trade?". Journal of International Economics. Vol. 81(1), pp. 75-88.

Kleimeier, S. and H. Sander. (2007). "Integrating Europe's Retail Banking Market". Brussels: Centre for European Policy Studies.

Kose, M.A., E. Prasad, K.S. Rogoff and S.-J. Wei. (2009). "Financial Globalization: A Reappraisal". IMF Staff Papers. Vol. 56(1), pp. 8-62. 
Oliver Wyman. (2012). "The Future of Asian Banking - Volume 2. Crouching Tigers - The Rise of Asian Regional Banks". Available: http://www.oliverwyman.com.

Reinhart, C.M. and V.R. Reinhart. (2009). "Capital Flow Bonanzas: An Encompassing View of the Past and Present", in: NBER International Seminar on Macroeconomics 2008.

Cambridge, MA: National Bureau of Economic Research, pp. 9-62.

Schoenmaker, D. (2011). "The Financial Trilemma". Economics Letters. Vol. 111(1), pp. 5759.

Schoenmaker, D. and S. Oosterloo. (2008). "Financial Supervision in Europe: A Proposal for a New Architecture", in: L. Jonung, C. Walkner and M. Watson (Eds.). Building the Financial Foundations of the Euro. Experiences and Challenges. London: Routledge, pp. 337-354.

Shirakawa, M. (2012). "Finance in Asia - Banking Business and Capital Markets". Keynote address at a dinner reception hosted by the Japan Securities Dealers Association, Tokyo, 9 February.

Speyer, B. (2011). "Financial supervision in the EU. Incremental Progress, Success Not Ensured". EU Monitor 84, Financial Market Special. 4 August, Deutsche Bank Research, Frankfurt am Main.

Subramanian, A. (2013). "Three New Lessons of the Euro Crisis". Project Syndicate. 8 April. Available: http://www.project-syndicate.org/commentary/what-the-eurozone-crisis-hastaught-economists-by-arvind-subramanian.

Véron, N. (2011). "The European Debt and Financial Crisis: Origins, Options". Congressional Testimony Submitted to the US Senate Committee on Banking, Housing, and Urban Affairs: Subcommittee on Security and International Trade and Finance. 22 September. Available: http://banking.senate.gov/public/index.cfm?FuseAction=Files.View\&FileStore_id=9bec6123d58d-423d-bf17-4fdcb9b113c3.

Volz, U. (2012a). "Lessons of the European Crisis for Regional Monetary and Financial Integration in East Asia". ADBI Working Paper No. 347. Tokyo: Asian Development Bank Institute.

Volz, U. (2012b). "The Need and Scope for Strengthening Co-operation between RFAs and the IMF". DIE Discussion Paper No. 15-2012. Bonn: German Development Institute.

Watson, M. (2012). "Financial Integration in Europe: Lessons from Ireland?", mimeo, European Studies Centre, St Antony's College, Oxford. 
Weill, L. (2009). "Convergence in Banking Efficiency across European Countries". Journal of International Financial Markets, Institutions and Money. Vol. 19(5), pp. 818-833.

Wyplosz, C. (2004). "Regional Exchange Rate Arrangements: Lessons from Europe for East Asia", in: Asian Development Bank (Ed.): Monetary and Financial Integration in East Asia. The Way Ahead. Vol. 2. Houndmills: Palgrave Macmillan, pp. 241-284. 
Box 1: ASEAN Economic Community Blueprint provisions regarding financial services sector liberalization and capital market development and integration

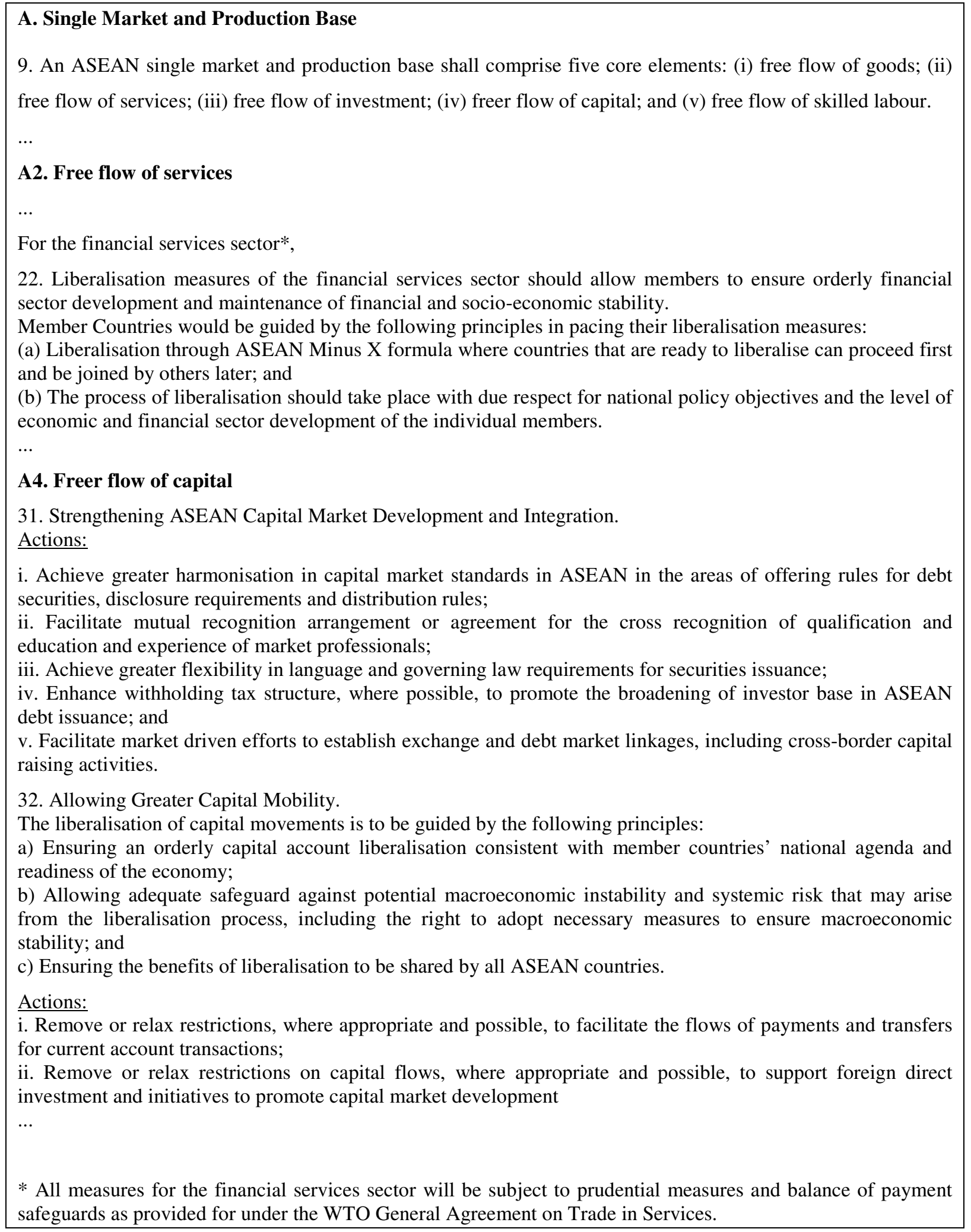

Source: ASEAN Secretariat (2008:11-12, 14-15). 
Table 1: Liberalization of banking activities in EU member states

\begin{tabular}{|c|c|c|c|c|}
\hline & $\begin{array}{l}\text { Lifting of capital } \\
\text { controls }\end{array}$ & $\begin{array}{l}\text { Interest rate } \\
\text { deregulation }\end{array}$ & $\begin{array}{c}\text { First Banking } \\
\text { Directive }\end{array}$ & $\begin{array}{c}\text { Second Banking } \\
\text { Directive }\end{array}$ \\
\hline Belgium & 1991 & 1990 & 1993 & 1994 \\
\hline Denmark & 1982 & 1988 & 1980 & 1991 \\
\hline France & 1990 & 1990 & 1980 & 1992 \\
\hline Germany & 1967 & 1981 & 1978 & 1992 \\
\hline Greece & 1994 & 1993 & 1981 & 1992 \\
\hline Ireland & 1985 & 1993 & 1989 & 1992 \\
\hline Italy & 1983 & 1990 & 1985 & 1992 \\
\hline Luxembourg & 1990 & 1990 & 1981 & 1993 \\
\hline Netherlands & 1980 & 1981 & 1978 & 1992 \\
\hline Portugal & 1992 & 1992 & 1992 & 1992 \\
\hline Spain & 1992 & 1992 & 1987 & 1994 \\
\hline UK & 1979 & 1979 & 1979 & 1993 \\
\hline
\end{tabular}

Source: Buch and Heinrich (2003:32). 
Table 2: General government gross debt (per cent of GDP)

\begin{tabular}{|c|c|c|c|c|c|c|c|c|c|c|c|c|c|c|c|c|c|}
\hline & 1995 & 1996 & 1997 & 1998 & 1999 & 2000 & 2001 & 2002 & 2003 & 2004 & 2005 & 2006 & 2007 & 2008 & 2009 & 2010 & 2011 \\
\hline EU (27 countries) & : & 69.9 & 68.3 & 66.4 & 65.8 & 61.9 & 61.0 & 60.5 & 61.9 & 62.3 & 62.8 & 61.6 & 59.0 & 62.2 & 74.6 & 80.0 & 82.5 \\
\hline Belgium & 130.2 & 127.2 & 122.5 & 117.2 & 113.6 & 107.8 & 106.5 & 103.4 & 98.4 & 94.0 & 92.0 & 88.0 & 84.0 & 89.2 & 95.7 & 95.5 & 97.8 \\
\hline Bulgaria & : & : & 108.3 & 77.6 & 77.6 & 72.5 & 66.0 & 52.4 & 44.4 & 37.0 & 27.5 & 21.6 & 17.2 & 13.7 & 14.6 & 16.2 & 16.3 \\
\hline Czech Republic & 14.0 & 11.9 & 12.6 & 14.5 & 15.8 & 17.8 & 23.9 & 27.1 & 28.6 & 28.9 & 28.4 & 28.3 & 27.9 & 28.7 & 34.2 & 37.8 & 40.8 \\
\hline Denmark & 72.6 & 69.4 & 65.4 & 61.4 & 58.1 & 52.4 & 49.6 & 49.5 & 47.2 & 45.1 & 37.8 & 32.1 & 27.1 & 33.4 & 40.6 & 42.9 & 46.6 \\
\hline Germany & 55.6 & 58.5 & 59.8 & 60.5 & 61.3 & 60.2 & 59.1 & 60.7 & 64.4 & 66.2 & 68.5 & 68.0 & 65.2 & 66.8 & 74.5 & 82.5 & 80.5 \\
\hline Estonia & 8.2 & 7.6 & 7.0 & 6.0 & 6.5 & 5.1 & 4.8 & 5.7 & 5.6 & 5.0 & 4.6 & 4.4 & 3.7 & 4.5 & 7.2 & 6.7 & 6.1 \\
\hline Ireland & 80.1 & 72.3 & 63.5 & 53.0 & 47.0 & 35.1 & 35.2 & 32.0 & 30.7 & 29.5 & 27.3 & 24.6 & 25.1 & 44.5 & 64.9 & 92.2 & 106.4 \\
\hline Greece & 97.0 & 99.4 & 96.6 & 94.5 & 94.0 & 103.4 & 103.7 & 101.7 & 97.4 & 98.6 & 100.0 & 106.1 & 107.4 & 112.9 & 129.7 & 148.3 & 170.6 \\
\hline Spain & 63.3 & 67.4 & 66.1 & 64.1 & 62.4 & 59.4 & 55.6 & 52.6 & 48.8 & 46.3 & 43.2 & 39.7 & 36.3 & 40.2 & 53.9 & 61.5 & 69.3 \\
\hline France & 55.5 & 58.0 & 59.2 & 59.4 & 58.9 & 57.3 & 56.9 & 58.8 & 62.9 & 64.9 & 66.4 & 63.7 & 64.2 & 68.2 & 79.2 & 82.3 & 86.0 \\
\hline Italy & 120.9 & 120.2 & 117.4 & 114.2 & 113.0 & 108.5 & 108.2 & 105.1 & 103.9 & 103.4 & 105.7 & 106.3 & 103.3 & 106.1 & 116.4 & 119.2 & 120.7 \\
\hline Cyprus & 51.8 & 53.1 & 57.4 & 59.2 & 59.3 & 59.6 & 61.2 & 65.1 & 69.7 & 70.9 & 69.4 & 64.7 & 58.8 & 48.9 & 58.5 & 61.3 & 71.1 \\
\hline Latvia & 15.1 & 13.9 & 11.1 & 9.6 & 12.5 & 12.4 & 14.1 & 13.6 & 14.7 & 15.0 & 12.5 & 10.7 & 9.0 & 19.8 & 36.7 & 44.5 & 42.2 \\
\hline Lithuania & 11.5 & 13.8 & 15.4 & 16.5 & 22.7 & 23.6 & 23.0 & 22.2 & 21.0 & 19.3 & 18.3 & 17.9 & 16.8 & 15.5 & 29.3 & 37.9 & 38.5 \\
\hline Luxembourg & 7.4 & 7 & 7.4 & 7.1 & 6.4 & 6.2 & 6.3 & 6.3 & 6.1 & 6.3 & .1 & 6.7 & 6.7 & 14.4 & 15.3 & 19.2 & 18.3 \\
\hline Hungary & 85.6 & 72. & 62.9 & 60.9 & 60.8 & 56.1 & 52.7 & 55.9 & 58.6 & 59.5 & 61.7 & 65.9 & 67.0 & 73.0 & 79.8 & 81.8 & 81.4 \\
\hline Malta & 35.3 & 40.1 & 48.4 & 53.4 & 57.1 & 54.9 & 60.5 & 59.1 & 67.6 & 71.7 & 69.7 & 64.0 & 61.9 & 62.0 & 67.6 & 68.3 & 70.9 \\
\hline Netherlands & 76.1 & 74.1 & 68.2 & 65.7 & 61.1 & 53.8 & 50.7 & 50.5 & 52.0 & 52.4 & 51.8 & 47.4 & 45.3 & 58.5 & 60.8 & 63.1 & 65.5 \\
\hline Austria & 68.2 & 68.1 & 64.1 & 64.4 & 66.8 & 66.2 & 66.8 & 66.2 & 65.3 & 64.7 & 64.2 & 62.3 & 60.2 & 63.8 & 69.2 & 72.0 & 72.4 \\
\hline Poland & 49.0 & 43.4 & 42.9 & 38.9 & 39.6 & 36.8 & 37.6 & 42.2 & 47.1 & 45.7 & 47.1 & 47.7 & 45.0 & 47.1 & 50.9 & 54.8 & 56.4 \\
\hline Portugal & 59.2 & 58.2 & 55.5 & 51.8 & 51.4 & 50.7 & 53.8 & 56.8 & 59.4 & 61.9 & 67.7 & 69.4 & 68.4 & 71.7 & 83.2 & 93.5 & 108.1 \\
\hline Romania & 6.6 & 10.6 & 15.0 & 16.8 & 21.7 & 22.5 & 25.7 & 24.9 & 21.5 & 18.7 & 15.8 & 12.4 & 12.8 & 13.4 & 23.6 & 30.5 & 33.4 \\
\hline Slovenia & 18.6 & 21.9 & 22.4 & 23.1 & 24.1 & 26.3 & 26.5 & 27.8 & 27.2 & 27.3 & 26.7 & 26.4 & 23.1 & 22.0 & 35.0 & 38.6 & 46.9 \\
\hline Slovakia & 22.1 & 31.1 & 33.7 & 34.5 & 47.8 & 50.3 & 48.9 & 43.4 & 42.4 & 41.5 & 34.2 & 30.5 & 29.6 & 27.9 & 35.6 & 41.0 & 43.3 \\
\hline Finland & 56.6 & 57.0 & 53.9 & 48.4 & 45.7 & 43.8 & 42.5 & 41.5 & 44.5 & 44.4 & 41.7 & 39.6 & 35.2 & 33.9 & 43.5 & 48.6 & 49.0 \\
\hline Sweden & 72.8 & 73.3 & 71.2 & 69.9 & 64.3 & 53.9 & 54.7 & 52.5 & 51.7 & 50.3 & 50.4 & 45.3 & 40.2 & 38.8 & 42.6 & 39.5 & 38.4 \\
\hline United Kingdom & 51.2 & 51.3 & 49.8 & 46.7 & 43.7 & 41.0 & 37.7 & 37.7 & 39.1 & 41.0 & 42.2 & 43.3 & 44.2 & 52.3 & 67.8 & 79.4 & 85.0 \\
\hline
\end{tabular}

Source: Compiled by author with data from Eurostat, April 2013.

Note: The shaded areas indicate a general government gross debt above 60 per cent of GDP. 


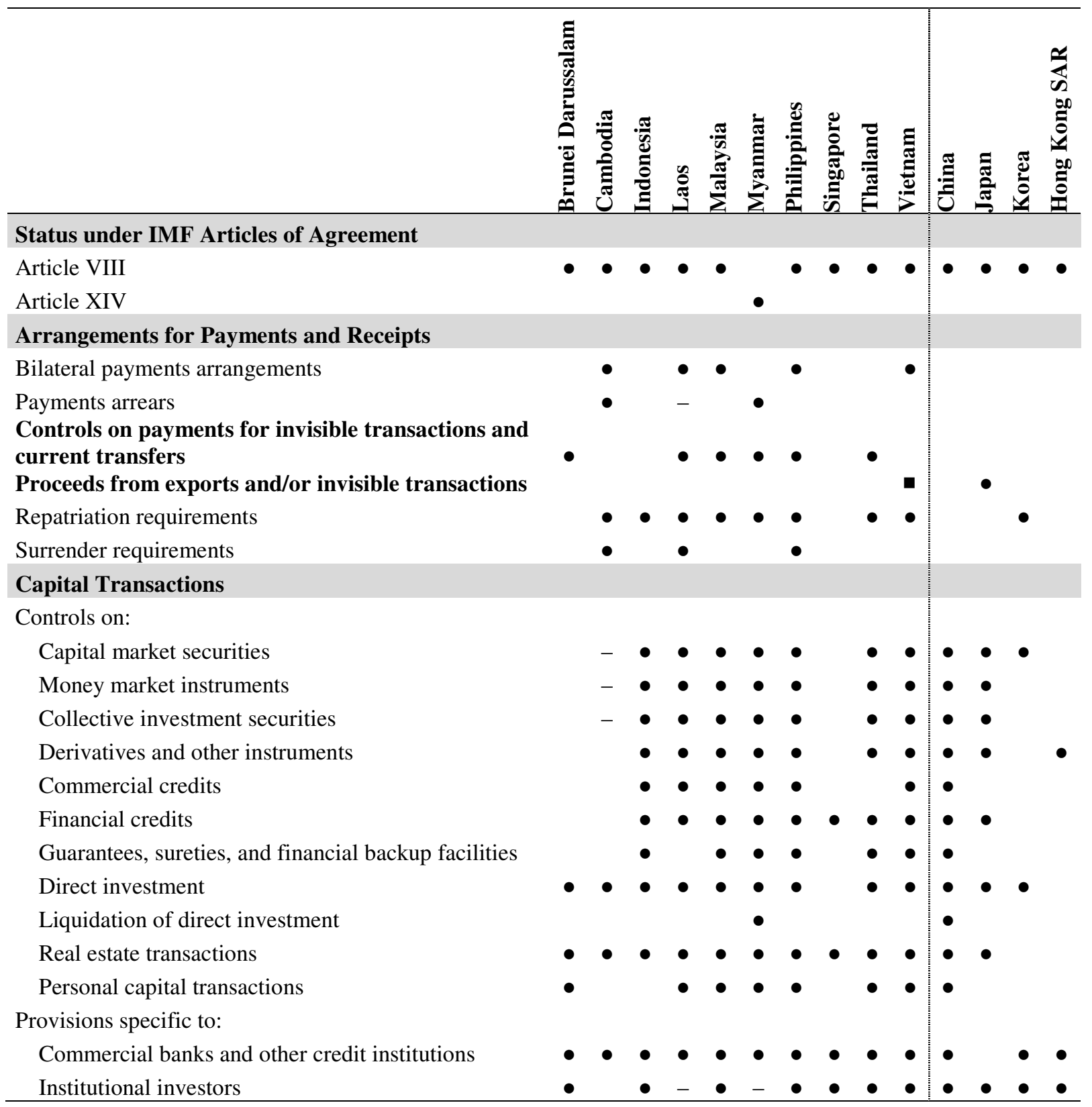

Source: Compiled by author with data from the IMF's 2012 Annual Report on Exchange Arrangements and Exchange Restrictions (IMF 2012).

Note: - Indicates that data were not available at the time of publication; a Indicates that the specified practice is not regulated. 
Figure 1: Chinn-Ito financial openness index for ASEAN+3 countries for 2011

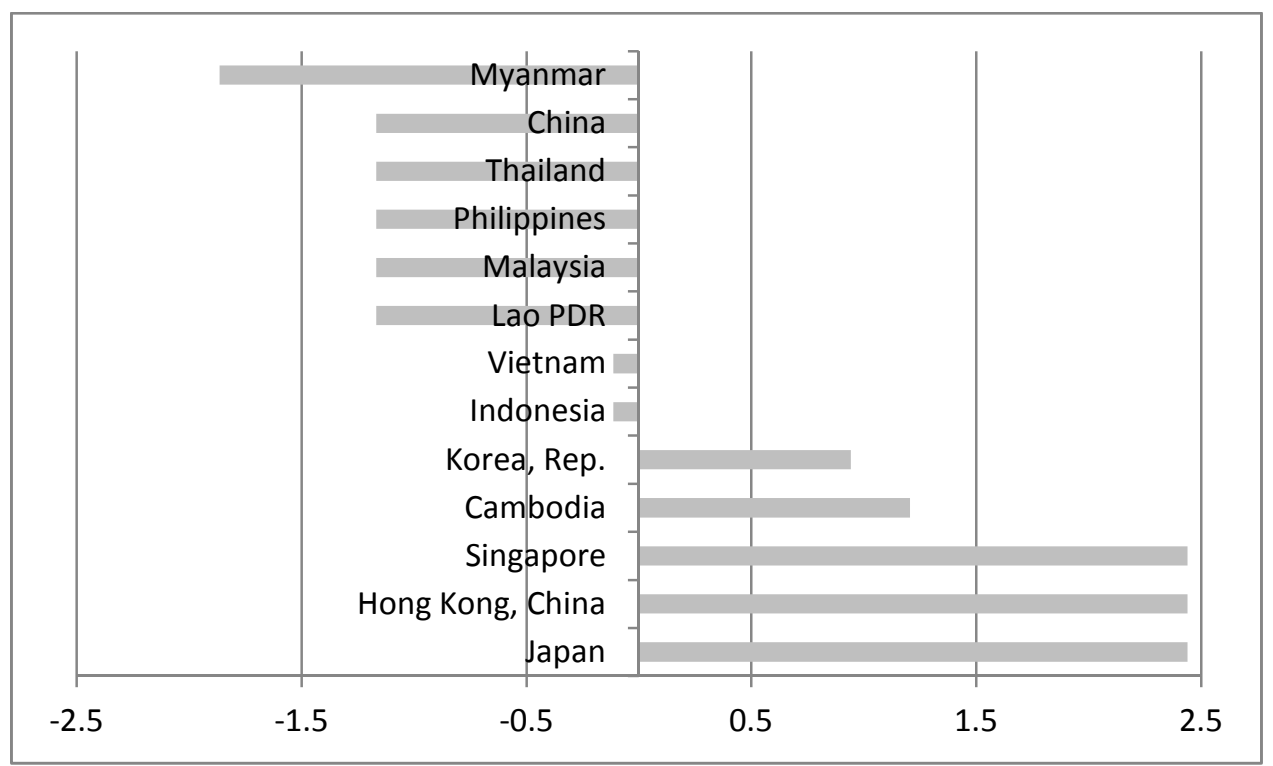

Source: Compiled by author with data from the Chinn-Ito index website, May 2013 (http://web.pdx.edu/ ito/Chinn-Ito_website.htm).

Note: The Chinn-Ito index is an index measuring a country's degree of capital account openness based on the binary dummy variables that codify the tabulation of restrictions on cross-border financial transactions reported in the IMF's Annual Report on Exchange Arrangements and Exchange Restrictions (cf. Chinn and Ito 2008). The index ranges from 2.5 to 2.5 , with the former indicating a closed and the latter an open capital account. 
Figure 2: The trilemma in financial supervision

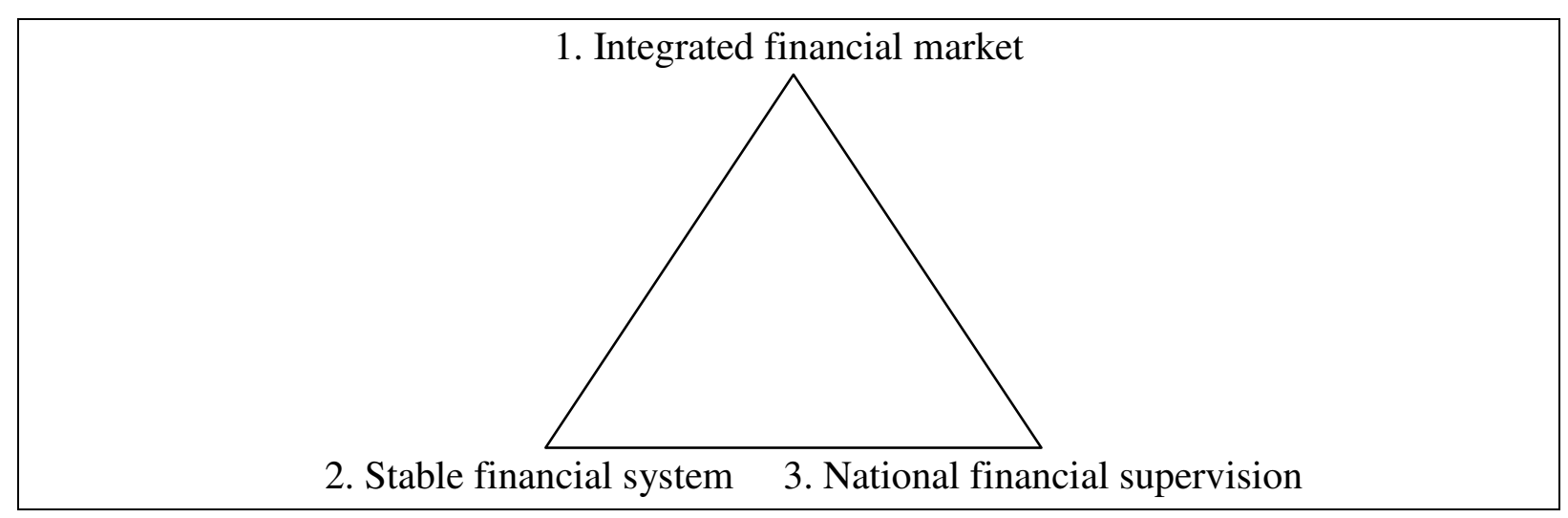

Source: Schoenmaker and Oosterloo (2008). 